SUSTAINABLE FORESTRY

COLLECTION 81-82, 2020
ODRŽIVO ŠUMARSTVO

ZBORNIK RADOVA 81-82, 2020

UDK 528.88:630*587.7(497.11 Stara planina) $=111$

Preliminary Communication

\title{
APPLICATION OF MULTISPECTRAL SENSORS AND UNMANNED AERIAL SYSTEM IN STARA PLANINA REGION
}

\author{
Nenad ŠURJANAC ${ }^{l}$, Marija MILOSAVLJEVIĆ ${ }^{l}$, \\ Mara TABAKOVIĆ-TOŠIĆ ${ }^{1}$, Miroslava MARKOVIĆ ${ }^{1}$
}

\begin{abstract}
In the area of Stara Planina mountain, a multispectral survey of forest vegetation was performed. Data acquisition was done with unmanned aerial system DJI Phantom 4 Pro, equipped with integrated RGB 20Mpix sensor, and MicaSense RedEdge M, 5-channel narrowband multispectral sensor. Data was collected in the form of images, and 4 composite orthomosaics were produced - broadband visible RGB, narrowband visible $R G B$, and with vegetation indices applied NDVI and NDRE. RGB orthomosaic showed no significant changes in canopies apart from the variability of levels of green. Orthomosaics with vegetation indices applied showed changes in the level of physiological activities of leaves. NDVI map showed the negative changes of the top of the canopies, while NDRE map showed more dramatic changes within the canopy as well. Besides the map, 5 polygons with different NDRE values were selected and their respective spectral signature graphs were produced. The areas with the lowest NDRE values had the highest reflectance values in all wavelengths, while the absorption of light is much higher in physiologically active vegetation. Values of NDRE lower than 0.479 were inspected from the ground. This kind of ground-truth provided evidence that the areas coded in red were with lower physiological activity due to the infestation by beech leaf-mining weevil Orchestes fagi L. Another interesting finding was that both NDVI and NDRE values were higher in the areas not directly exposed to the sunlight. The areas shaded by surrounding canopies received only diffuse light but it showed a more positive ratio between absorbed and reflected wavelength which could be characteristic of the Fagus Sylvatica species. The findings in this study showed a strong correlation between low values NDRE vegetation index and negative changes deep within the canopy of high vegetation, which can serve as an indicator of pest infestation in forestry
\end{abstract}

${ }^{1}$ Institute of Forestry, Belgrade, Serbia 
Keywords: multispectral sensor, vegetation indices, forestry, remote sensing, leafmining weevil, MicaSense, drones, DJI Phantom, Metashape.

\section{PRIMENA MULTISPEKTRALNIH SENZORA I BESPILOTNIH LETELICA U REGIONU STARE PLANINE}

Izvod: $U$ regionu Stare Planine izvršeno je snimanje šumske vegetacije multispektralnim senzorom. Prikupljanje podataka je urađeno bespilotnom letelicom DJI Phantom 4 Pro, opremljenom sa integrisanom RGB kamerom rezolucije 20 Mpix, $i$ MicaSense RedEdge M uskokanalnom multispektralnom kamerom. Podaci su prikupljeni u obliku fotografija od kojih su proizvedeni 4 kompozitna ortomozaika - širokopojasni u vidljivom delu spektra, uskokanalni $u$ vidljivom delu spektra, $i 2$ ortomozaika sa primenjenim vegetacijskim indeksima - NDVI i NDRE. RGB ortomozaici nisu pokazali značajne promene u krošnjama, osim očekivanih različitih nijansi zelene boje. Ortomozaici sa primenjenim vegetacijskim indeksima pokazali su promene u nivoima fiziološke aktivnosti listova. NDVI mape su pokazale negativne promena u najvišim delovima krošnje, dok su NDRE mape pokazale dramatičnije promene $i$ dublje u krošnjama. Na mapama je izdvojeno 5 poligona sa različitim NDRE i NDVI vrednostima, na osnovu čijih vrednosti refleksije su izrađeni grafikoni spektralnih potpisa. Područja sa najnižim vrednostima NDRE su imale najviše vrednosti refleksije na svim talasnim dužinama, dok je absorpcija svetla mnogo viša u fiziološki aktivnoj vegetaciji. Biljke sa delovima koji su imali vrednosti NDRE indeksa manje od 0,479 su proverene sa zemlje. Ovakvo uzorkovanje i provera su pružili dokaze da su površine klasifikovane kao loše zaista bile lošeg zdravstvenog stanja usled infestacije bukvinim minerom (Orchestes fagi L). Interesantan nalaz je bila pojava da su vrednosti oba indeksa bile najviše u delovima krošnje koji su bili zaklonjeni od direktne sunčeve svetlosti. Delovi koji su bili u dubokoj senci su primali samo difuznu svetlost, ali su imali daleko pozitivniji odnos između absorbovane $i$ reflektovane svetlosti, što može bi i spektralna karakteristika bukve kao vrste. Rezultati prikazani u ovom radu pokazali su snažnu povezanost između niskih vrednosti NDRE vegetacijskog indeksa i negativnih promena $u$ krošnji visoke vegetacije, što se može koristiti kao indikator infestacija štetočinama $u$ šumarstvu.

Ključne reči: multispektralni senzor, vegetacijski indeksi, šumarstvo, daljinska detekcija, bukvin miner, MicaSense, dronovi, DJI Phantom, Metashape.

\section{INTRODUCTION}

Every surface, alive or dead, has certain spectral properties that are represented in certain spectral reflectance. Reflectance is a measure of how much energy a certain surface reflects at a specific wavelength (Humbolt State University, Introduction to Remote Sensing). The patterns of spectral reflectance belonging to certain surfaces are called spectral signatures. Every surface that reflects light, and therefore can be seen has a spectral signature. These signatures describe the underlying properties of the surfaces. Spectral reflectance signatures result from the presence or absence, as well as the position and shape of specific absorption features of the surface (Huete, 2004). When it comes to the vegetation the most important features that have an impact on the shape of the spectral reflectance curve, and the levels of reflectance of certain wavelengths are biochemical and biophysical 
characteristics, 3D cellular organization (Ustin and Jacquemoud, 2020), and chlorophyll pigments. They dominate absorption and reflectance in the wavelength range between 400 and $700 \mathrm{~nm}$ (Huete, 2004). Chlorophyll-a and Chlorophyll-b absorb wavelengths between $400-500 \mathrm{~nm}$ and $600-700 \mathrm{~nm}$ for photosynthesis. Xanthophyll is blue leaf pigment, which strongly absorbs light of wavelengths between 400-500 $\mathrm{nm}$, and alongside red pigment is responsible for colors of leaves in deciduous plants (Huete, 2004). Every vegetation undergoing the stress gives off a different spectral response - spectral signature under the effect of stress on leaf pigments.

Wavelengths between 780-900nm are not significantly absorbed by healthy leaves (Merzlyak et al, 2002). Near-Infrared (NIR) part of the spectrum, 700-1300 $\mathrm{nm}$ does not interact with leaf pigments. It goes through them and reflects most of the energy in a healthy and well-functioning leaf structure. Stressed plants reflect a lower amount of energy in NIR part of the spectrum, which in combination with a higher amount of energy in 400-700 nm parts of the spectrum is evidence of stress in plant (Huete, 2004).

Sharp rise between Red and NIR parts of the spectrum is called Red Edge, and the levels of reflected energy in that part of the spectrum is very suitable for the detection of stress in plants. Reflectance near 700nm is a very sensitive indicator of chlorophyll concentration (Gitelson et al., 1996).

Spectral reflectance signatures provide information about the state, geochemical composition, and structure of leaf and canopy (Huete, 2012).

The way to quantify the information on the physiological activity of plants is to use the spectral vegetation indices or simply vegetation indices. These indices represent the numerical values that are related to the amount of stress in the plants. There are various numerical ranges of those values, depending on the algorithm used.

Most often spectral indices use reflectance values of 2 contrasting wavelengths, one with high absorbance and the one with high reflectance. Such an example is the widely used NDVI - Normalized Difference Vegetation Index. That index shows the ratio between NIR, which has high reflectance, and Red wavelength which has high absorbance. Chlorophyll absorbs visible light, while the cellular structure of leaves reflects NIR light (NASA, Measuring Vegetation, NDVI and EVI indices).

Stress such as dehydration, pest or fungi infestation, or pathogen caused stress causes spongy layers of leaves to deteriorate (Slaton et al. 2001). This further causes absorption instead of reflectance of NIR light. At the same time reflectance of Red light increases. This affects the numerical values of NDVI to become low. This is a fairly good indicator of stress in plants. The limitation of this particular vegetation index is saturation which occurs once the canopies are fully developed or even earlier, depending on plant species. This can lead to results being falsely high.

To avoid this saturation, using the part of the spectrum that can "penetrate" the upper layers of the canopy, brings information from the depth of the canopy. The part of the spectrum that allows this is Red Edge. The ratio between NIR and Red Edge levels of reflectance gives more information about the whole plant instead of the top levels of the canopy. 


\section{LOCATION - STUDY AREA}

Area of interest for this paper was mixed coniferous/broadleaf forest located at Stara Planina, in Eastern Serbia (image 1.). This was especially due to the presence of European Beech (Fagus sylvatica L.). Details on position and vegetation are presented in Table 1.

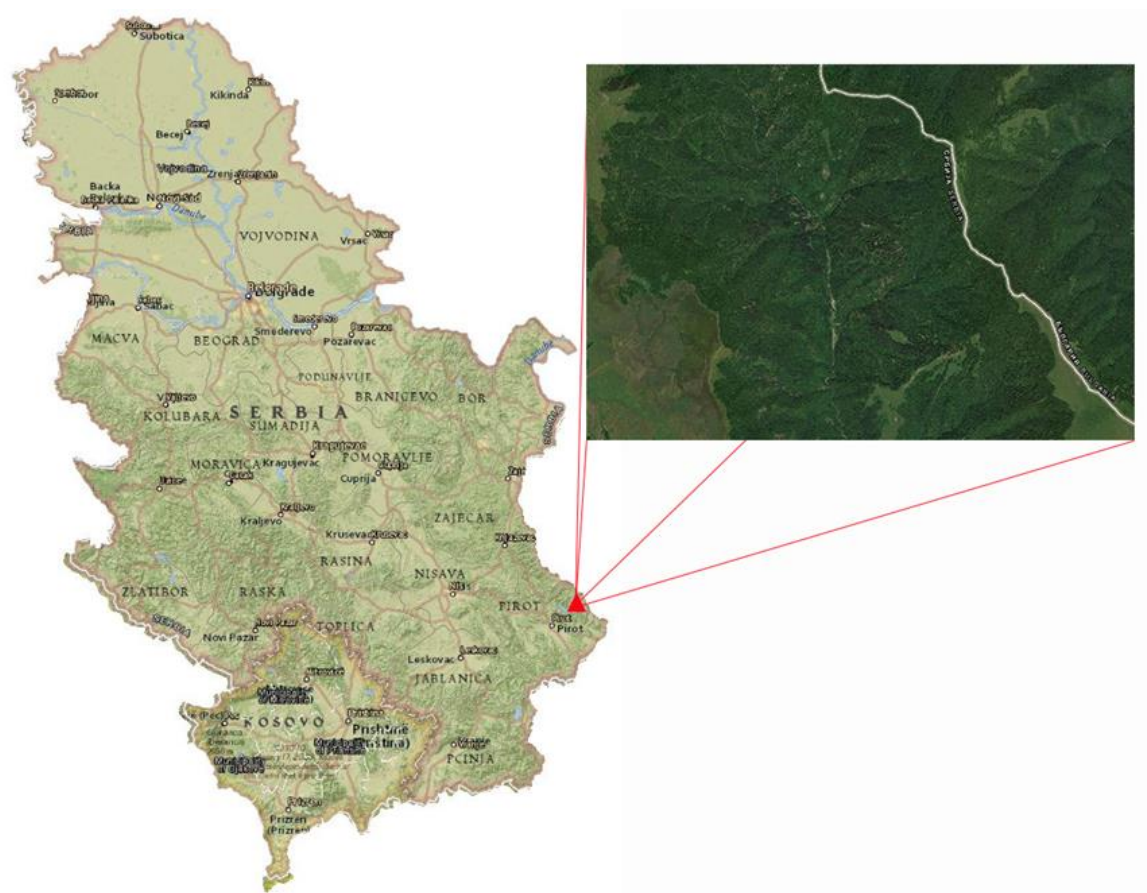

Image 1. Study area location

Table 1. Location information

\begin{tabular}{|c|c|c|c|c|c|c|c|}
\hline Plot & $\begin{array}{l}\text { Forest } \\
\text { Estate }\end{array}$ & $\begin{array}{c}\text { Management } \\
\text { unit }\end{array}$ & $\begin{array}{c}\text { Forest } \\
\text { Compartment }\end{array}$ & $\begin{array}{c}\text { Coordinates } \\
\text { WGS84 }\end{array}$ & Altitude & $\begin{array}{c}\text { Type of } \\
\text { soil }\end{array}$ & $\begin{array}{c}\text { Type of } \\
\text { forest }\end{array}$ \\
\hline 1 & \multirow{3}{*}{ Pirot } & \multirow{3}{*}{$\begin{array}{l}\text { Stara Planina } \\
\text { / Široke Luke }\end{array}$} & 42 & \multirow{3}{*}{$\begin{array}{l}\text { N } 43^{\circ} 15^{\prime} 32^{\prime \prime} \\
\text { E } 22^{\circ} 50^{\prime} 45^{\prime \prime}\end{array}$} & \multirow{3}{*}{1068} & \multirow{3}{*}{ Brown } & \multirow{3}{*}{$\begin{array}{c}\text { Sessile } \\
\text { Oak } \\
\text { Forest - } \\
\text { High } \\
\end{array}$} \\
\hline 2 & & & 43 & & & & \\
\hline 3 & & & 44 & & & & \\
\hline
\end{tabular}

\section{MATERIAL AND METHODS}

In the period from the $12^{\text {th }}$ to the $17^{\text {th }}$ of August 2020, preliminary screening of several areas located at the Stara Planina Mountain was performed.

Equipment used for data acquisition was unmanned aerial system (UAS) DJI Phantom 4 Pro, equipped with onboard 20 Megapixel RGB sensor, and narrowband multispectral sensor MicaSense RedEdge M.

Flight altitude was 100 meters above ground level. This ensured resolution of $\sim 4 \mathrm{~cm} /$ pixel for multispectral, and $2.5 \mathrm{~cm} /$ pixel for RGB sensor. 
Deployment of UAS is suitable for surveying hard-to-reach areas, it is fast and easy to deploy, it has a minimal impact on the environment, and it can cover large areas in short times (Šurjanac et al. 2019).

Collected data was in the form of individual overlapping images. Broadband RGB sensor collected 3-channel data in the visible range of wavelengths 400-700 $\mathrm{nm}$. It consists of Red, Green, and Blue channels, each having 256 levels of intensity. Multispectral images come as 5-channel images consisting of visible range wavelengths - Red, Green, Blue, and non-visible range - Red Edge and NearInfrared. Narrowband multispectral sensor has 5 individual sensors that collected images in separate bands. The sensitivity of every channel is represented with 65536 levels of intensity. This provides the ability to detect fine levels of stress and difference between various levels of physiological activities in plants.

Remotely sensed images can contain errors and noise due to the sensor construction and/or environmental conditions. Radiometric calibration is, therefore, a prerequisite in digital image processing, especially in biophysical analyses (Wang and Myint, 2015). To overcome different weather and light conditions before and after every imaging session calibration images were taken. Calibration images are 5channel images of Calibrated Reflectance Panel, which has known values of different wavelengths. Calibration of images is of the utmost importance when working with spectral reflectance values. Poorly calibrated images will produce improper values of the reflectance which will lead to bad conclusions and decisions. This kind of problem is defined as GIGO - Garbage In - Garbage Out.

All images were gathered during the course of 10 minutes to prevent otherwise partially cloudy weather from impacting recorded reflectance values. RGB and multispectral images were collected simultaneously - the drone carried both sensors at the same time. The total amount of images from the multispectral camera was 2,415 , which actually are 483 5-channel co-registered images. Co-registration is the process of fine matching the images taken with multisensory cameras of camera rigs. Without a proper co-registration process the multispectral images would end up blurry and useless. Co-registration is done automatically in the photogrammetric software. The software that was used for photogrammetric analyses of the images was Agisoft Metashape Professional 1.6.4. and Trimble eCognition for advanced object-based image analyses.

Initial analyses included co-registration of the images, production of a sparse and dense point cloud, production of digital elevation model, and orthomosaic, which consists of stitched and overlapped images.

The second level of analyses was performed in Trimble eCognition, which grouped pixels with similar properties throughout all channels and layers, and formed objects which are better representatives of properties than individual pixels. This allowed classification based on vegetation index values and better delineation of the various plants and multicriteria classification.

Final data analyses and presentation was performed in QGIS and MS Excel. 


\section{RESULTS AND DISCUSSION}

The final product of initial processing and pixel-based analyses are composite orthomosaics in visible wavelengths and color-coded thematic maps with applied 2 vegetation indices - NDVI and NDRE.

Map created with NDVI index provided information about the conditions that are prevailing in the top levels of the canopies. There was no significant variation within deciduous species of trees. The variation of NDVI index was notable in various vegetation types and different cover types, such as road, and water surfaces.

NDRE index provided much more information valuable for differentiation of physiological activity of the plants and detection of areas with increased levels of stress in plants. This was used to detect the area of deciduous trees, between road and stream. This area had lower values of the index, which are an indicator of physiological stress.

The main three wavelength bands used as indicators were Red, Red Edge, and Near Infra-Red. The color-coded maps with the representation of the values of these 3 bands are shown in image 2, 3 and 4 .

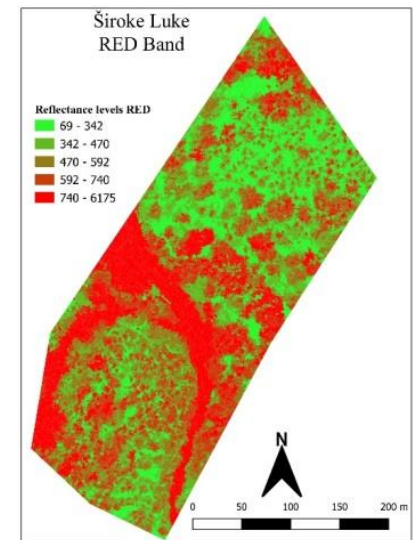

Image 2. Reflectance Red band

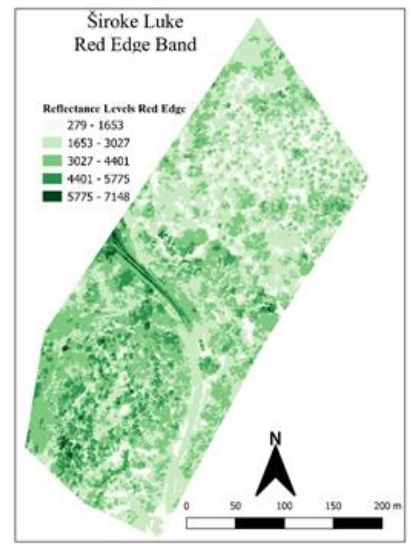

Image 3. Reflectance Red Edge band

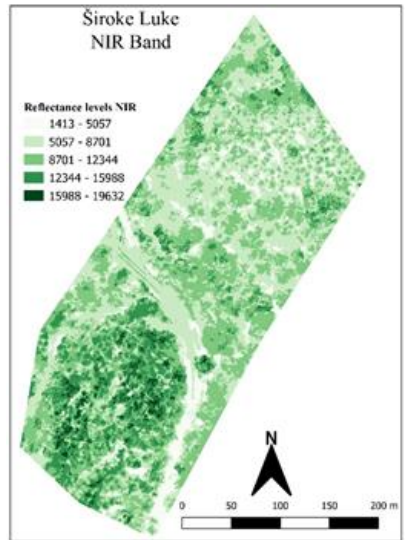

Image 4. Reflectance Near Infra-Red

Chlorophyll normally absorbs wavelengths corresponding with blue and red colors. High reflectance of the red band indicates potential issues of physiological activity (Image 2). However, the single band can't be used individually. The analyses of other bands such as Red Edge and NIR bands which are affected by spongy tissue in leaves also provide significant insight into the physiological activity of the plants.

Image 3. and Image 4. present color-coded values of Red Edge and NIR bands reflectance. In healthy plants, these values should be high. As the health deteriorates reflectance in these bands lowers.

But just like with the red band, the values of Red edge and NIR bands are not sufficient for a definite indication of plants' physiological activity. This is well presented in spectral signature graphs of the NDRE vegetation index. Here the parts of the image with the lowest values, which indicates the poorest health, have the highest reflectance values in each captured wavelength. 
As stated above, a healthy plant will reflect more NIR energy than an unhealthy plant from the same amount of incoming light. In this image selected color-coding represents low NIR energy as pale green, while the strongest reflectance is colored dark green. The distribution of the color shows which areas have low reflectance which should indicate potential issues.

Here certain areas have very low Red Edge reflectance. From the terrain survey and from the digital surface model it can be seen that those areas belong to the lower parts of the canopies, thus receiving less direct sunlight. These parts of the canopy rely only on diffused light, thus having lower amounts of reflected energy.

A very similar distribution was noticed at the wavelengths in the NIR region. Again, very low reflectance in areas in lower parts of the canopy. Relying on this information "As Is" could lead to the conclusion that lower parts of the canopy have lower levels of activity. 1. Showes the dark blue line, with the NDRE value of 0.65 which actually belongs to the lowest parts of the canopy.

To get to the numerical values of health levels of physiological activity ratio of reflectance between at least 2 layers should be used. Each layer represents 1 discrete wavelength. These ratios are vegetation indices. To detect changes 2 vegetation indices were used - Normalized Difference Vegetation Index (NDVI), and Normalized Difference Red Edge index (NDRE).

NDVI values tend to saturate in closed canopies, which is why it has falsely high values. NDRE can bring out the data deeper from the canopies and provide more reliable data in closed canopies.

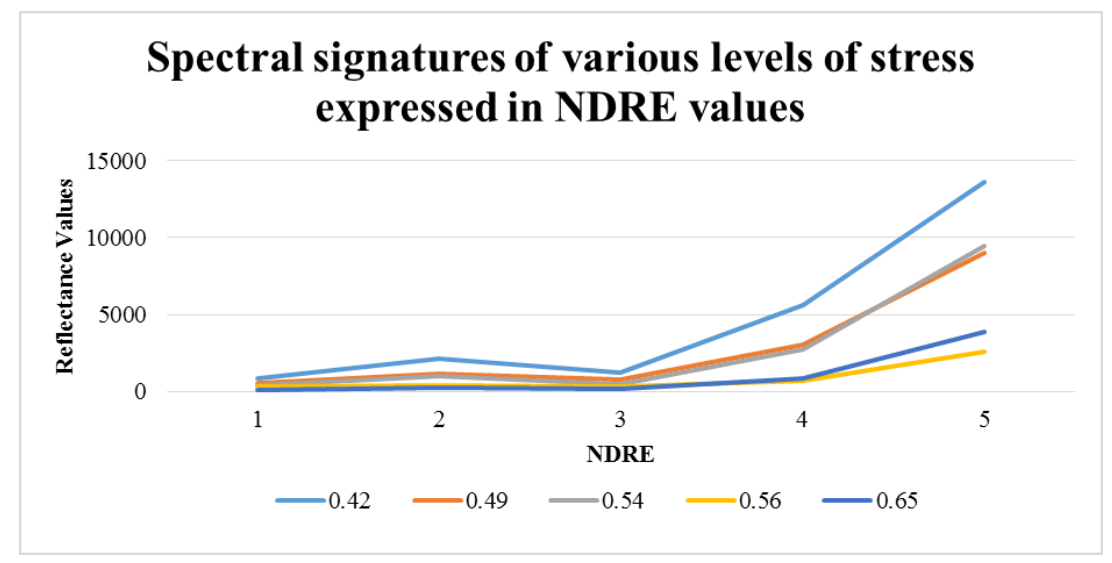

Graph 1. Spectral signatures of 5 sample polygons with NDRE values

Graph 1 and 2 show how the same spectral signatures produce very different values and trends in various vegetation indices, which further have different indications on vegetation health. Data for graphs were sampled from 5 different classes of vegetation index values.

NDVI showed mostly what was happening in the surface levels of the canopies of the deciduous trees. Data in graphs 2 . showed how 5 samples produced values of NDVI from 0.77 to 0.91 .

On the other hand, Graph 1. showed a wide range of NDRE index values from 0.42 to 0.65 . 


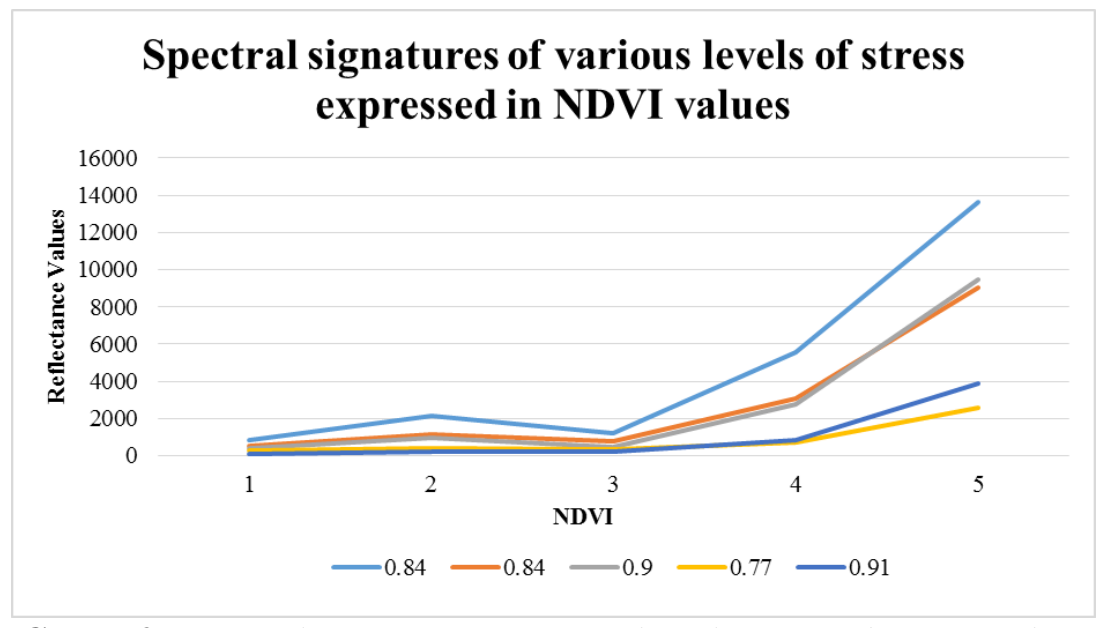

Graph 2. Spectral signatures of 5 sample polygons with NDVI values

Image 5. and image 6. shows the map in visible wavelength range, while image 7. and image 8. show maps with applied NDVI and NDRE vegetation indices.

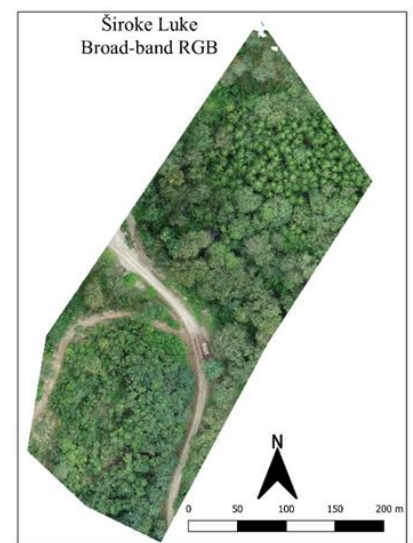

Image 5. RGB Broad band

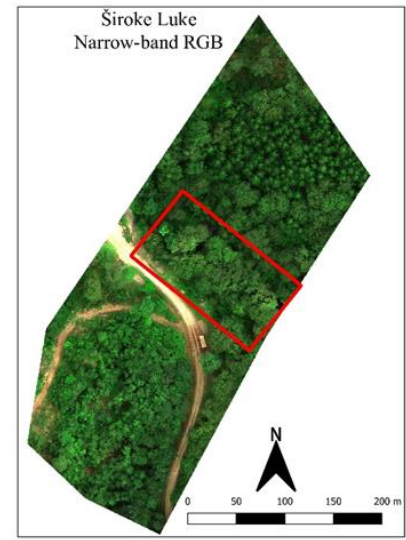

Image 6. $R G B$ Narrow band with sample area

Images in RGB - visible range, made from the broad sensor and narrow band multispectral sensor, showed no significant differences between healthy and stressed vegetation. The broadband sensor provided high resolution, with a lot of detail, but still, no changes were visible on vegetation. Narrowband RGB had more contrast, and even though it provided more insight into subtle changes in color intensity, no index of negative changes in vegetation was observable. 


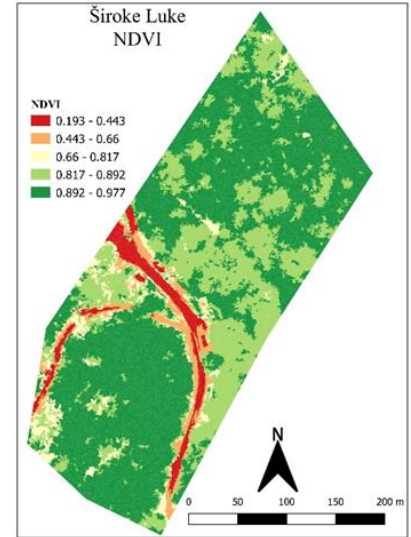

Image 7. NDVI thematic map

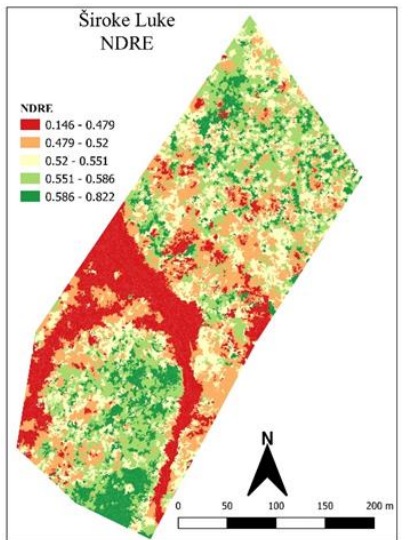

Image 8. NDRE thematic map

Maps with applied vegetation indices showed similar areas of interest. NDVI values showed that certain areas have lower levels of activity, but it was still very high activity according to the index values. This is very likely to be associated with the saturation of NDVI.

NDRE map pointed out areas with higher levels of stress. These areas are colored red, and even though there was some correlation with areas with lower NDVI values, the NDRE map provided more distinctive values for stress identification.

For the purpose of the ground truth, area just north of the road was inspected (Image 6). It was confirmed that the area detected the drone was infested with beech weevil Orchestes fagi L. (Coleoptera: Curculionidae: Curculioninae) (Image 8). The beech leaf-mining weevil (Orchestes fagi L.) is one of the most dangerous pests attacking the leaves of common beech (Fagus sylvatica L), (Miteva et al.). Larvae feed on the parenchyma tissue of the leaves destroying the most important part of the process of photosynthesis, leaving only the epidermis, which consequently diminishes the growth of the tree (Sweeney et al. 2012). The mine provides living and feeding quarters for the larva. In this area, over $80 \%$ of all beech trees were attacked by beech leaf-mining weevil.

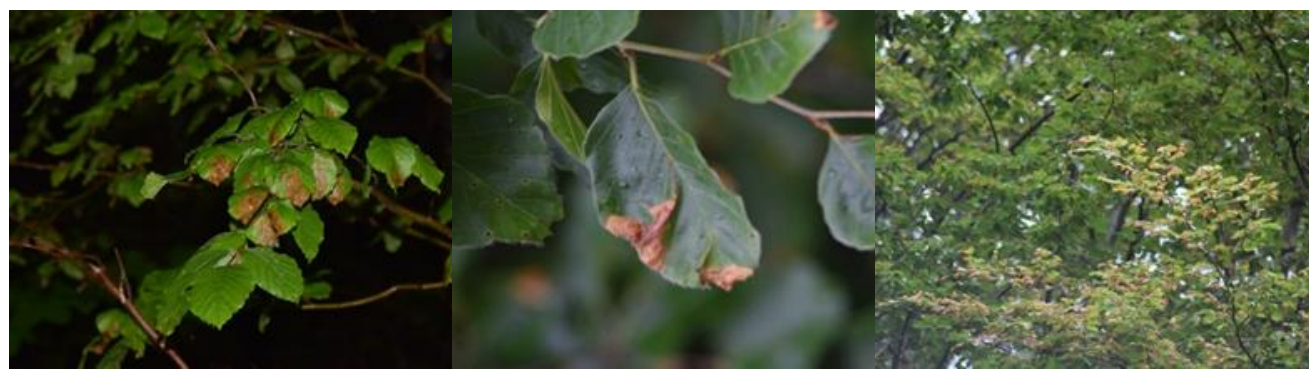

Image 9. The beech leaf-mining weevil (Orchestes fagi L.)

The significance of Orchestes fagi $\mathrm{L}$ in the Beech forest of Serbia is important. The previous research has shown that within the framework of ICP Forest, In 51 out of 125 sample plots which were set ( 869 beech trees out of 2,860 trees), Orchestes fagi $\mathrm{L}$ was found on 21 out of 51 sample plots where beech presence was 
recorded, i.e. on 93 out of 869 trees. The presence of this pest was reported on $10.7 \%$ of trees and on $41.2 \%$ of the sample plots (Radulović and Milanović, 2009).

\section{CONCLUSION}

Application of UAS and multispectral sensors in forestry had the purpose of providing a sufficient amount of data for pinpointing the areas affected by stress and/or pest infestation. The method has proven to be very successful for monitoring vitality and health status, as well as detecting possible causes of their disturbance. In the case of the beech weevil, it was proven that this group of plants had endangered health. The total range of the index is ranged from -0.3 to 0.7 . The early detection of harmful organisms and categorization of bands from the multispectral camera which indicates that is a specific organism detect is a future study for forest monitoring. The especially positive result was the fact that data from over 1 hectare can be gathered for less than a minute, and detect early stress, which would lead to the protection of economically and environmentally valuable resources. Another aspect of the results was the detection of the various physiological activity of leaves on a single tree, depending on different exposure to sunlight.

\section{REFERENCES}

Gitelson, A.A., Merzlyak, M.N., Lichtenthaler, H.K., (1996): Detection of Red Edge Position and Chlorophyll Content by Reflectance Measurements Near $700 \mathrm{~nm}$. Journal of Plant Physiology, Volume 148, Issues 3-4, Pages 501-508.

Huete, A.R. (2004): Remote Sensing For Environmental Monitoring, Environmental Monitoring and Characterization, Academic Press, Pages 183-206.

Huete, A.R. (2012): Vegetation Indices, Remote Sensing and Forest Monitoring. Geogr. Compass, 6, 513-532.

Merzlyak, M.N., Chivkunova, O.B., Melø, T.B., Naqvi, R.K.(2002): Does a leaf absorb radiation in the near infrared $(780-900 \mathrm{~nm})$ region? A new approach to quantifying optical reflection, absorption and transmission of leaves. Photosynthesis Research 72, 263-270 - 5

Miteva, L., Dimitrova, P., Ivanov, S., Ivanova, E., Kershev, P., Sergiev, I., Ovcharov, D. and Alexieva, V. (2007): Beech weevil (Orchestes fagi L.) affects antioxidant defense of Fagus sylvatica. Poster session at international workshop "Plant Biology \& Botany 2007", 07-12 July 2007. Chicago, Illinois.

Radulović, Z., Milanović, S. (2009): The health condition of beech forests on ICP sample plots in Serbia. Sustainable Forestry,54-55, p.129.

Slaton, M., Hunt, E., \& Smith, W. (2001): Estimating Near-Infrared Leaf Reflectance from Leaf Structural Characteristics. American Journal of Botany, 88(2), 278-284. - 8

Springer, C., Wang, C., Myint, S. W., (2015): A Simplified Empirical Line Method of Radiometric Calibration for Small Unmanned Aircraft Systems-Based Remote Sensing, 
IEEE Journal of Selected Topics in Applied Earth Observations and Remote Sensing, vol. 8, no. 5 , pp. $1876-1885$

Sweeney, J., Anderson, R.S., Webster, R.P. and Neville, R. (2012): First records of Orchestes fagi (L.)(Coleoptera: Curculionidae: Curculioninae) in North America, with a checklist of the North American Rhamphini. The Coleopterists Bulletin, 66(4), pp.297-304. - 11.

Šurjanac, N., Momirović, N., Milosavljević, M., Braunović, S., Kabiljo, M. (2019): Application of small unmanned aerial systems in logistics and planning, Institute of forestry, SUSTAINABLE FORESTRY Collection of papers, Volume 79-80, pages 149-164.

Ustin S.L., Jacquemoud S. (2020): How the Optical Properties of Leaves Modify the Absorption and Scattering of Energy and Enhance Leaf Functionality. In: CavenderBares J., Gamon J., Townsend P. (eds) Remote Sensing of Plant Biodiversity.

Humbolt State University, Introduction to Remote Sensing

NASA, Measuring Vegetation, NDVI and EVI indices

\title{
APPLICATION OF MULTISPECTRAL SENSORS AND UNMANNED AERIAL SYSTEM IN STARA PLANINA REGION
}

\author{
Nenad ŠURJANAC, Marija MILOSAVLJEVIĆ, \\ Mara TABAKOVIĆ-TOŠIĆ, Miroslava MARKOVIĆ
}

\begin{abstract}
Summary
Multispectral imaging provides information on the physiological activity of plants. Levels of reflectance in wavelengths in Near-Infrared and Red Edge parts of the spectrum are sensitive to chlorophyll content and molecular structure of leaves. Stress-induced changes in leaves strongly influence the levels of reflectance. In Stara Planina region, measurement of levels of reflectance in mixed forest stands was performed to test the ability of drone-borne multispectral sensors to detect subtle changes in reflectance caused by stress from pest infestation (Orchestes Fagi L) in European beech (Fagus sylvatica L). Data acquisition was performed with narrow-band multispectral sensor MicaSense RedEdge M, in 5 discrete channels, and RGB digital camera in 3-channel images. Data processing was done in professional photogrammetry, and GIS software. Even though inspection of invisible parts of the spectrum did not reveal any changes in vegetation, application of vegetation indices NDVI and NDRE provided information not only which trees showed lower levels of physiological activities, but also indicated which parts of the trees had more or less stress. The finding from the drone was confirmed through ground-truthing (observation and sampling). This paper showed a positive correlation between the application of multispectral sensors for stress identification in forestry and observation from the ground which indicates that reliable results may be obtained in a fast and effective manner from the application of drones in forestry.
\end{abstract}




\title{
PRIMENA MULTISPEKTRALNIH SENZORA I BESPILOTNIH LETELICA U REGIONU STARE PLANINE
}

\author{
Nenad ŠURJANAC, Marija MILOSAVLJEVIĆ, \\ Mara TABAKOVIĆ-TOŠIĆ, Miroslava MARKOVIĆ
}

\section{Rezime}

Multispektralni snimci nam pružaju informacije o fiziološkoj aktivnosti biljaka. Intenziteti reflektovane svetlosti na talasnim dužinama koje pripadaju Blisko-Infracrvenom i Ivično-crvenom delu spektra su osetljivi na promene u koncentraciji hlorofila i molekularne strukture lista. Promene na listovima koje su uzrokovane stresom imaju jak uticaj na intenzitete reflektovane svetlosti. U regionu Stare Planine, izvršena su merenja intenziteta reflektovane svetlosti sa listova u mešovitoj šumi kako bi se utvrdila mogućnost primene multispektralnih senzora sa dronova. Od naročitog interesa je bila primena u detekciji finih promena u refleksiji na Evropskoj bukvi koja je izazvana štetočinama, konkretno bukvinim surlašem (Orchestes Fagi L). Prikupljanje podataka ja izvršeno uskokanalnom multispektralnom kamerom MicaSense RedEdge M i standardnom kamerom za snimanje u vidljivom delu spektra. Podaci su prikupljani u obliku 5-kanalnih i 3-kanalnih RGB fotografija, i obrađeni su profesionalnim fotogrametrijskim i GIS softverom. Iako pregledom podataka u vidljivom delu spektra nije bilo indikacija o stresu, primenom vegetacijskih indeksa - NDVI i NDRE ukazano je ne samo na stabla sa nižom fiziološkom aktivnošću, već su i detektovani delovi stabala sa većim ili manjim stresom. Svi nalazi dobijeni na osnovu podataka sa drona su provereni i potvrđeni na osnovu terenskih observacija i uzorkovanja. U ovom radu je prikazana pozitivna korelacija između informacija u šumarstvu dobijenih multispektralnim senszorom i terenskim observacijama, što ukazuje na mogućnost dobijanja pouzdanih podataka na brz i efikasan način primenom dronova u šumarstvu. 